\title{
Pharmacognostic Evaluation and Determination of Secondary Plant Metabolites by HPTLC and its Antioxidant Activity in Myrica esculenta
}

\author{
Prashant Kumar ${ }^{1}$, Abhishek Gupta ${ }^{2}$, Anita Singh ${ }^{1 *}$
}

\section{Prashant Kumar', Abhishek Gupta², Anita Singh ${ }^{1 *}$}

\section{'Department of Pharmaceutical Sciences Kumaun University Bhimtal, Uttarakhand, INDIA. \\ ${ }^{2}$ Pharmacognosy \& Ethnopharmacolo- gy Division, CSIR-NBRI, Lucknow, INDIA. \\ Correspondence \\ Dr. Anita Singh*}

Department of Pharmaceutical Sciences, Kumaun University, Bhimtal, Uttarkhand, INDIA.

Phone no: 9719803500

E-mail: dr.anitaku@gmail.com

\section{History}

- Submission Date: 02-06-2017;

- Review completed: 10-07-2017;

- Accepted Date: 02-11-2017

DOI : 10.5530/pj.2017.6s.165

Article Available online

http://www.phcogj.com/v9/i6s

\section{Copyright}

(c) 2017 Phcog.Net. This is an openaccess article distributed under the terms of the Creative Commons Attribution 4.0 International license.

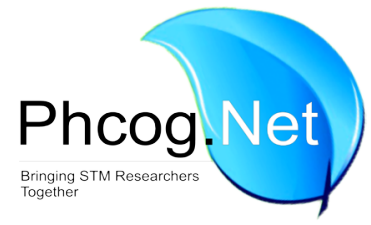

\begin{abstract}
Introduction: Myrica esculenta Buch.-Ham. (Myricaceae) is commonly known as Box Berry, Kaiphal, and Katphala in Ayurveda. As per the Ayurvedic literature the palnt is used for variety of diseases and disorders. Method: The present study deals with the pharmacognostical standardization, HPTLC analysis and antioxidant activity of methanolict extracts of the leaves of $M$. esculenta. The plant showed high phenolic and flavonoid content. In-vitro antioxidant study of dried leaves of Myrica esculanta was performed using methanolic extract. Results: Antioxidant activity of $M$. esculenta methanolic extract showed the least $I C_{50}$ value of $60 \pm$ $1.15 \mu \mathrm{g} / \mathrm{ml}$. Standard ascorbic acid showed an $I C_{50}$ value of $2.03 \pm 0.06 \mu \mathrm{g} / \mathrm{ml}$. The calibration curve of Gallic acid showed $r^{2}$ of 0.949 and $R_{f}$ of gallic acid was found to be $0.44 \pm 0.006$. Quantification of gallic acid in the samples of leaves of $M$. esculenta has been performed and the gallic acid was found to be $0.056 \%$. Conclusion: The presence of gallic acid has not yet been reported and quantified in this species which may be utilized for the proper standardization of the drug. The present study showed new natural antioxidant that can replace the synthetic ones to be used in foods and cosmetics.
\end{abstract}

Key words: Antioxidant, DPPH, Myrica Esculenta, Gallic Acid, HPTLC.

\section{INTRODUCTION}

Medicinal plants have been in use since ancient times by all cultures as medicines, as herbal remedies and are proved as economical with minor side effects. These attributes of a plant depend on the type of phytoconstituents present in it. Due to the high therapeutic values of the medicinalplants, during thelastonedecade, the efficacy and safety have been stressed out. Myrica esculenta Buch.-Ham. (Myricaceae) is commonly known as Box Berry, Kaiphal, and Katphala in Ayurveda. As per the Ayurvedic literature, stem bark of this plant is used in gulma (abdominal tumors), jvara (fever), arsa (piles), grahani (irregular bowel function), pandu roga (anemia), hrillasa (nausea), mukha roga (oral disorders), kasa (cough), svasa (dyspnea), agnimandhya (indigestion), aruchi (anorexia),allergic disorders and kantharoga (ears, nose, and throat disorders). ${ }^{1,2}$ It is a medium sized tree, $3-15 \mathrm{~m}$ high found in the subtropical or outer Himalaya. The medicinal properties of M. Esculenta are well known as per ethnobotanical surveys.

The stem bark mainly contains gallic acid, castalagin ${ }^{3}$ myricanol, myricanone, ${ }^{4}$ epigallocatechin 3-O-gallate, epigallocatechin- $(4 \beta \rightarrow 8)$-epigallocatechin 3 -O-gallate, 3-O-galloylepigallocatechin- $(4 \beta \rightarrow 8)$-epigallocatechin3-O-gallate, proanthocyanidin, catechine, delphini- dine chloride ${ }^{5}$ quercetin, $\beta$-sitosterol, taraxerol and triterpene diol. ${ }^{6}$

The bark Possess anti-inflammatory ${ }^{7}$ anti-helmintic ${ }^{8}$ anti-microbial, ${ }^{9,10}$ anxiolytic, ${ }^{11}$ while the fruits are known for their anti-oxidant properties and Antimicrobial nature ${ }^{12,13}$ The whole plant is an effective chemo preventive agent in skin. ${ }^{14}$ Conventionally, foremost tribal communities of Uttarakhand exploit the bark revealing its ethonobotanical importance. It is well known to be effective in chronic cough, asthma and ear ache. When the bark powder is applied externally, it heals chronic and malignant ulcers, and also to intoxicate the fishes. ${ }^{15}$ In Ayurveda, the plant is known to have antispasmodic, antiinflammatory, analgesic properties. ${ }^{16}$ The antibacterial activity of fruit and bark of the plant has been performed earlier. ${ }^{17}$ Till now there are so many Synthetic antioxidants are commercially available but quite unsafe, and their toxicity is a distressing trouble. ${ }^{18}$ The natural antioxidants, mainly phenolics and flavonoids, are safe, having prominent biological activity, so the current focuses on natural antioxidants from natural plants. Some researchers have worked earlier on standardization of stem bark by using HPTLC and developed a method for the identification of the biomarkers gal-
Cite this article: Kumar P, Gupta A, Singh A. Pharmacognostic Evaluation and Determination of Secondary Plant Metabolites by HPTLC and Its Antioxidant Activity in M. esculenta. Pharmacog J. 2017;9(6)Suppl: s103-s6. 
lic acid, lupeol, oleanolic acid, and stigmasterol in the stem bark extract of $M$. esculenta, ${ }^{19,20}$ but no work has been explored on the phytochemical screening and physicochemical evaluation on leaves of this plant till date. Therefore the present study deals with the pharmacognostical standardization, HPTLC analysis and antioxidant activity of methanolic extract of the leaves of M. esculenta.

\section{MATERIALS AND METHODS}

\section{Chemicals and Reagents}

1,1Diphenyl -2-picrylhydrazyle (DPPH) and Gallic acid were obtained from Sigma Aldrich Co. All other chemicals used were of analytical grade.

\section{Plant material}

Collection of Plant: The plant specimen, i.e. dried leaves of Myrica esculanta (Myricaceae) were collected from nothern himalayan region of Garhwal Uttarakhand, India in the month of March 2015 from the height of 1685.53 Meters N $29.8688^{\circ} \mathrm{N}, 78.8383^{\circ} \mathrm{E}$. The plants were identified and authenticated in BSI, Allahabad, India. A voucher specimen has been submitted in the Institute's herbarium.

\section{Preparation of Plant Extracts}

The fresh plant material was collected, thoroughly washed with water to remove all debris and then shade dried. The dried material was powdered by using an electric grinder at 100 mesh sizes. Extraction was performed by soxhlation process in two steps. Firstly the powdered material was defatted under soxhlet assembly using $250 \mathrm{~mL}$ of $98 \%$ ether for 6 hours. This is followed by 9 hours soxhlation of defatted powder by using $250 \mathrm{~mL}$ of methanol as solvent. The final extracts were passed through Whatman No. 1 filter paper. The filtrates obtained were concentrated under vacuum in a rotary evaporator at $40^{\circ} \mathrm{C}$ and stored at $4^{\circ} \mathrm{C}$ for further use. The crude extracts were obtained by dissolving a known amount of dry extract in $98 \%$ methanol to obtain a stock solution of $1000 \mu \mathrm{g} / \mathrm{ml}$. The stock solutions were serially diluted with the respective solvents to obtain lower dilutions $(25,50,100,125,150,200,250,300$ and $500 \mu \mathrm{g} / \mathrm{ml})$.

\section{Physicochemical and Phytochemical Studies}

Physicochemical and Phytochemical studies, like extrasfive values, total ash, acid insoluble ash, total sugar, starch, phenols and flavonoids were calculated from the shade-dried and powdered (60 mesh) plant material. ${ }^{21-24}$

\section{Antioxidant Activity (DPPH Free Radical Scavenging Activity)}

The antioxidant activity of the plant extracts and standard was assessed on the basis of the radical scavenging effect of the stable DPPH free radical by the method previously described.22 The diluted working solutions of the test extracts were prepared in methanol. Ascorbic acid was used as the standard in solutions ranging from 1 to $50 \mu \mathrm{g} / \mathrm{ml}$. $0.002 \% \mathrm{DPPH}$ solution in methanol was prepared. Then $2 \mathrm{ml}$ of this solution was mixed with $2 \mathrm{ml}$ of sample solutions (ranging from $25 \mu \mathrm{g} / \mathrm{ml}$ to $500 \mu \mathrm{g} / \mathrm{ml}$ ) and the standard solution to be tested separately. These solution mixtures were kept in the dark for $30 \mathrm{~min}$ and the optical density was measured at $517 \mathrm{~nm}$ using a Shimadzu spectrophotometer against methanol. The blank used was $2 \mathrm{ml}$ of methanol with $2 \mathrm{ml}$ of DPPH solution $(0.002 \%)$. The optical density was recorded and percentage of inhibition was calculated using the equation: \% of inhibition of DPPH activity $=(\mathrm{A}-\mathrm{B}) /$ $\mathrm{A} \times 100$; where $\mathrm{A}$ is optical density of the blank and $\mathrm{B}$ is optical density of the sample. ${ }^{25}$

\section{HPTLC Studies}

Air dried $\left(45-55^{\circ} \mathrm{C}\right)$ powdered Myrica esculanta (Myricaceae) $(2.0 \mathrm{~g})$ in triplicate were extracted separately with 3 X $20 \mathrm{ml}$ methanol. Extracts were concentrated under vacuum and redissolved in methanol, filtered and finally made up to $100 \mathrm{ml}$ with methanol prior to HPTLC analysis. ${ }^{26}$ Reagents used were from Merk (Germany) and standard gallic acid was procured from Sigma-Aldrich (Steinheim).

\section{Chromatographic Conditions}

Chromatography was performed on Merk HPTLC precoated silica gel 60GF254 $(20$ X $20 \mathrm{~cm})$ plates. Methanolic solutions of samples and standard compound gallic acid of known concentrations were applied to the layers as $6 \mathrm{~mm}$-wide bands positioned $15 \mathrm{~mm}$ from the bottom and $15 \mathrm{~mm}$ from side of the plate, using Camag Linomat $\mathrm{V}$ automated TLC applicator with the nitrogen flow providing a delivery speed of $150 \mathrm{nl} / \mathrm{s}$ from the application syringe. These conditions were kept constant throughout the analysis of samples.

\section{Detection and Quantification of Gallic acid}

Following sample application, layers were developed in a Camag twin trough glass chamber which was pre-satarrested with a mobile phase of toluene: ethyl acetate: formic acid (5:5:1) till the proper separation of bands up to $8 \mathrm{~cm}$ height. After development, layers were dried with an air dryer and gallic acid was simultaneously quantified using Camag TLC scanner model 3 equipped with Camag Wincats IV software. Following scan conditions were applied: slit width, $5 \mathrm{~mm}$ x $0.45 \mathrm{~mm}$; wavelength, $320 \mathrm{~nm}$; and absorption-reflection mode. In order to prepare calibration curves, a stock solution of Gallic acid $(1 \mathrm{mg} / \mathrm{ml})$ was prepared and various volumes of the solution were analyzed through HPTLC, calibration curves of peak area vs. concentration were also prepared.

\section{RESULTS}

\section{Phytochemical screening}

Phytochemical screening for the hydro-alcoholic extract showed positive test for flavonoids, proteins, carbohydrates, glycosides, phenolic compounds and saponins, Table1.

\section{Physicochemical Studies}

Parameters such as moisture content, extractive values (Water, alcohol and ether soluble), total ash and acid insoluble ash values, total sugar, total starch, and total phenolics were determined, Figure 1.

\section{Antioxidant activity}

In-vitro antioxidant study of dried leaves of Myrica esculanta was performed using methanolic extract. In this study M. esculenta methanolic extract showed the least $\mathrm{IC}_{50}$ value of $60 \pm 1.15 \mu \mathrm{g} / \mathrm{ml}$. Standard ascorbic acid showed an $\mathrm{IC}_{50}$ value of $2.03 \pm 0.06 \mu \mathrm{g} / \mathrm{ml}$. The methanolic plant extract showed a promising antioxidant activity, Table 2.

\section{HPTLC Studies}

The calibration curve of Gallic acid showed $r^{2}$ of 0.949 and $R_{f}$ of gallic acid was found to be $0.44 \pm 0.006$. Quantification of gallic acid in the samples of leaves of $M$. esculenta has been performed and the gallic acid was found to be $0.056 \%$. A Densitogram and banding pattern obtained from extract shows gallic acid, Figure 2.

\section{DISCUSSION AND CONCLUSION}

The plant was initially evaluated for its phytochemical \& physicochemical parameters. The plant showed high phenolic \& flavonoid content, which was the basis for further evaluation of plant for its antioxidant activity 


\section{Table 1: Phytochemical Screening of Myrica esculanta}

\begin{tabular}{ccccc} 
Metabolites & Hexane & Chloroform & Alcohol & Water \\
\hline Alkaloids & - & + & + & - \\
Glycosides & - & - & + & + \\
Tannins & - & - & + & + \\
Saponins & - & - & + & + \\
Flavonoids & - & - & + & + \\
Protein & - & - & - & - \\
Carbohydrates & - & - & + & + \\
\hline
\end{tabular}

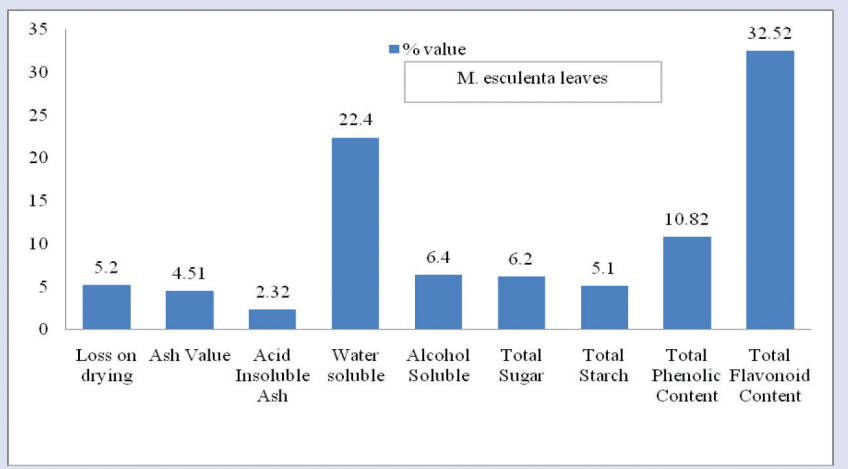

Figure 1: Percentage physicochemical values of $M$. esculenta leaves

Table 2: Antioxidant activity (DPPH Free Radical Scavenging Activity)

\begin{tabular}{ccc}
\hline S.No. & Sample & DPPH assay $\mathrm{IC}_{50}(\mu \mathrm{g} / \mathrm{mL})$ \\
\hline 1. & Ascorbic acid standard & $2.03 \pm 0.06$ \\
2. & Methanolic plant extract & $60 \pm 1.15$ \\
\hline
\end{tabular}

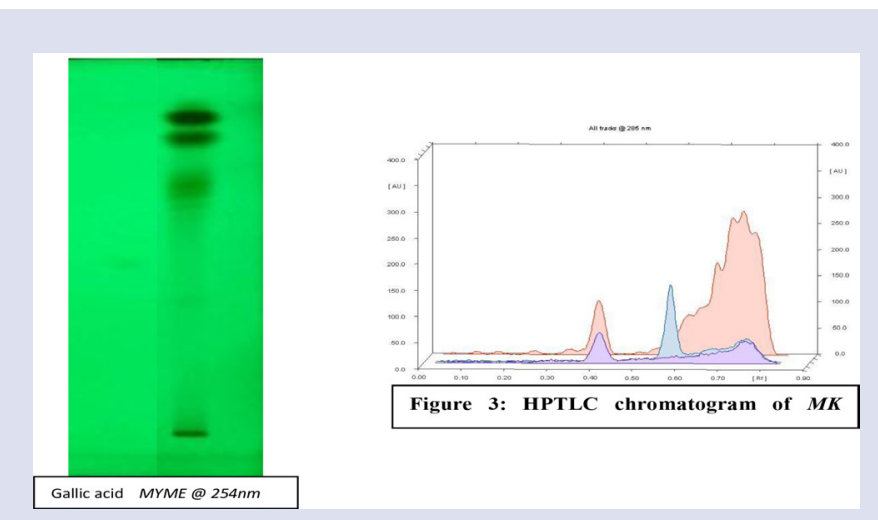

Figure 2: HPTLC Chromatogram of Plant Extracts showing different bands

and identification as well as quantification of its phenolic markers by HPTLC.

Ascorbic acid (standard compound) showed highest significant and potent antioxidant activity in DPPH free radical scavenging method. The methanolic extract showed a promising activity.
Presence of phenolic compounds in M. esculenta suggests that the antioxidant activity may be due to the polyphenolic content. Identification of all chemical constituents in extract those are responsible for antioxidant activity requires further investigation, the crude extracts merits further experiments in-vivo. Gallic acid, a potential antioxidant present in this species, has been studied through HPTLC. The presence of gallic acid has not yet been reported and quantified in this species which may be utilized for the proper standardization of the drug.

The present study showed new natural antioxidant that can replace the synthetic ones to be used in foods and cosmetics. Thus, the effective source of $M$. esculenta could be employed in all medicinal preparations to combat major problems associated with oxidative stress and related disorders.

\section{ACKNOWLEDGEMENT}

The authors are thankful to Department of Pharmaceutical Sciences, Faculty of Technology, Kumaun University, Bhimtal, Nainital-263136, Uttarakhand for providing all the facilities to conduct this research work.

\section{CONFLICT OF INTEREST}

The authors declare no conflict of interest

\section{ABBREVIATION USED}

DPPH: 1,1Diphenyl -2-picrylhydrazyle; HPTLC: High Performance Thin Layer Chromatography; $\mathrm{IC}_{50}$ : percent inhibition at $50 \%$ concentration.

\section{REFERENCES}

1. Anonymous. Ayurvedic Pharmacopeoeia of India. Part I, vol I. Department of Health, Ministry of Health and Family Welfare, Government of India, New Delhi. 2004;92-3.

2. Patel KG, Rao NJ,Gajera VG, Bhatt PA,Patel KV, Gandhi TR. Anti-allergic Activity of Stem Bark of Myrica esculenta Buch.-Ham. (Myricaceae). J Young Pharm. 2010;2(1):74-8.

3. Singh J, Lan V.K, Trivedi V.P. Pharmacognostic evaluation of katphala (The bark of Myrica esculenta Buch - Ham). Anc Sci Life. 1986;6(2):85-7.

4. Dawang S, Zuchun Z, Wong H, Lai Y.F. Tannins and other phenolics from Myrica esculenta bark. Phytochemistry. 1988; 27(2):579-83.

5. Krishnamoorthy $V$, Seshadri T.R. A new proanthocyanidin from the stem bark of Myrica nagi thumb. Tetrahedron. 1966;22(7):2367-71.

6. Agarwal K.P, Roy A.C, Dhar M.L. Triterpenes from the bark of Myrica esculenta Buch - Ham. Indian J Chem. 1963;1(1):28-30.

7. Patel T, Rajshekar C, Parmar R. Mast cell stabilizing activity of bark of $M$. nagi. Int J Pharm Stu Res. 2011;2:1-6.

8. Jain VK, Jain B. Anthihelmintic activity of ethanolic extract of bark of Myrica esculenta. Int J Pharm Sci Res. 2010;1(11):129-31.

9. Suryawanshi JS, Karande KM, Udugade BV. Antibacterial activity of bark and fruits of M. nagi. Ind J Nat Prod. 2009; 25(3):21-3.

10. Shan B, Cai YZ, Brooks JD, Corke H. The in- vitro antibacterial activity of dietary spice and medicinal herb extracts. Int J Food Microbiol. 2007;117(1):112-19

11. Khan MY, Sagrawat H, Upmanyu N, Siddique S. Anxiolytic properties of M. nagi bark extract. Pharm Biol. 2008;46(10-11):757-61.

12. Rawat S, Jugran A, Giri L, Bhatt ID, Rawal RS. Assessment of antioxidant properties in fruits of Myrica esculenta: A popular wild edible species in Indian Himalayan Region ECAM. 2010;1:1-8.

13. Saklani S, Chandra S, Mishra AP, Badoni PP. Nutritional evaluation, antimicrobial

14. activity and Phytochemical Screening of Wild edible fruit of $M$. nagi pulp. Int J Pharm

15. Pharmaceut Sci. 2012;1(1):10

16. Alam A, Iqbal M, Saleem M, Ahmed SU, Sultana S. M. nagi Attenuates cumene hydroperoxide-induced cutaneous oxidative stress and toxicity in swiss albino mice. Pharmacol Toxicol. 2000;86(5):209-14

17. Jeeva S, Lyndem FG, Sawian JT, Laloo RC, Mishra BP. Myrica esculenta Buch.Ham. Ex D.Don.- a potential ethnomedicinal species in a subtropical forest of Meghalaya, northeast India. Asian Pac J Trop Biomed. 2011;1(2):S174-S7.

18. Panthari $P$, Kharkwal $H$, Kharkwal $H$, Joshi DD. M. nagi: A review on active constituents, biological and therapeutic effects. Int J Pharm Pharmaceut Sci. 2012;4(5):38-42 
19. Suryawanshi JS, Karande KM, Udugade BV. Antibacterial activity of bark and fruits of M. nagi. Ind J Nat Pro. 2009;25(3):21-3.

20. Jing Z, Ke Y, Wen-long Z, Jian Z, Ping Y. Studies on the active components and antioxidant activities of the extracts of Mimosa pudica Linn. from southern China. $2011 ; 7(25): 35-9$

21. Singh N, Khatoon S, Srivastava N, Rawat A, Mehrotra S. Qualitative and quantitative standardization of Myrica esculenta Buch.-Ham. Stem bark by use of HPTLC. JPC-Journal of Planar Chromatography-Modern TLC. 2009;22(4):287-91.

22. Srivastava B, Vikas C, Pramila P, Pandey N.K , and Jadhav A.D. Evaluation for substitution of stem bark with small branches of Myrica esculenta for medicinal use - A comparative phytochemical study. J Ayurveda Integr Med. $2016 ; 7(4): 218-23$.

23. Peach K, Tracy MV. Modern Methods of Plant Analysis. Vol III and IV Springer, Heidelberg. 1955;258-61.
24. Anonymous. Indian pharmacopoeia, Government of India, Ministry of Health and Family Welfare, Controller of Publications, New Delhi. 2007;191-2

25. Anonymous. Official methods of Analysis (AOAC), $4^{\text {th }}$ edn. Association of Official Chemists, Inc. U.S.A; 198;187-8

26. Yang W, Tang CM, Li X, Zhou Y, Wang L, Li L. Study on the chemical constituents of Myrica esculenta. JYunnan Univ (Natural Sciences) 2011;33:453-7.

27. Gupta A, Verma S, Kushwaha P, Srivastava S, Rawat AK. Phytochemical and antioxidant studies of Salvadora persica L. stem and twig. Indian J Pharm Educ Res. 2015;49(1):71-5.

28. Abhishek Gupta, Shikhar Verma, Sayyada Khatoon, Harinath Dwivedi, and Ajay K.S. Rawat. High-Performance Thin-Layer Chromatographic Analysis for the Simultaneous Quantification of Four Phenolics in Flowers and Flower Buds of Bauhinia purpurea L., Bauhinia variegata L., and Bauhinia acuminata L. Journal of Planar Chromatography. 2015;28(6):452-7.

\section{GRAPHICAL ABSTRACT}

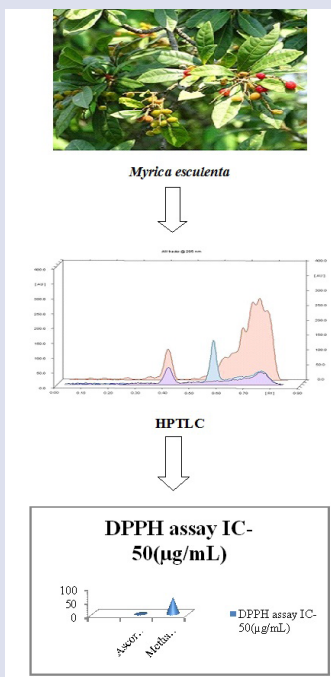

ANIOXIDANT ACTIVITY DPPH ASSAY

\section{SUMMARY}

- In present research work different phytochemical \& physicochemical parameters were performed on Myrica esculenta leaves extract for its standardization.

- The quantification of gallic acid in the samples of $M$. esculenta leaves has been performed by HPTLC analysis and the gallic acid was found to be $0.056 \%$

- Antioxidant activity of methanolic extract of $M$. esculenta was estimated by DPPH method and the $\mathrm{IC}_{50}$ value was found to be $60 \pm 1.15 \mu \mathrm{g} / \mathrm{ml}$.

\section{ABOUT AUTHORS}

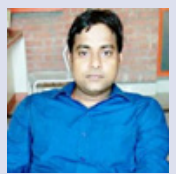

Prashant Kumar: Is working as research scholar in Department of Pharmaceutical Sciences, Kumaun University Bhimtal, Uttarkhand, India. Has sound experience in nanoparticulate drug delivery systems of medicinal plants.

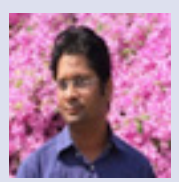

Abhishek Gupta: Worked as young scientist fellow in Pharmacognosy \& Ethnopharmacology Division, CSIR-National Botanical Research Institute, Lucknow. His research arena is method development for analysis of medicinal plants in Phytochemistry and Phytoteraphy division.

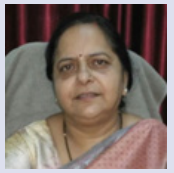

Dr. Anita Singh: Senior Assistant professor in Department of Pharmaceutical Sciences, Kumaun University Bhimtal, Uttarkhand, India. She has a wide experience in medicinal chemistry in Pharmacy department. Develop work in Phytochemistry and Phytoteraphy from plants.

Cite this article: Kumar P, Gupta A, Singh A. Pharmacognostic Evaluation and Determination of Secondary Plant Metabolites by HPTLC and Its Antioxidant Activity in Myrica esculenta. Pharmacog J. 2017;9(6)Suppl: s103-s6. 